\title{
1. Colonial legacies: family laws in Singapore and Australia
}

\author{
Ann Black
}

\section{INTRODUCTION}

Situated on the Asia-Pacific rim, the two island states of Singapore and Australia are each home to approximately half a million Muslims. In both nations there is a significant and recognisable Muslim minority: 3 per cent in Australia and 15 per cent in Singapore. In both, Islam is the religion with the third largest number of faith adherents after Christianity and Buddhism, with Hinduism fourth. Australia and Singapore also have a large number of citizens who have no religious affiliation, around 20 per cent. Both are secular states, with neither Constitution proclaiming a state religion. Each nation is proud of its multi-ethnic, multi-religious and multicultural polity, and both triumph in the respective ways by which they have maintained overall national cohesion. Singapore's Chief Justice Chan Sek Keong describes multiculturalism as Singapore's 'way to a harmonious society'. ${ }^{1}$ It creates Singapore's identity and builds a cohesive society from the different racial communities through belief in shared values and then 'sharing those common values in their daily lives'.2 Former Prime Minister Gillard described Australia's multiculturalism as more than the ability to maintain diverse backgrounds and cultures, saying that it acts as a "meeting place of rights and responsibilities' including 'non-negotiable respect for our foundational values of democracy and the rule of law'. ${ }^{3}$

Both share a common legal heritage. Singapore and Australia were colonised by Britain two centuries ago, thereby becoming inheritors of the common law legal system with its attending institutions, methodology

1 Chan Sek Keong, 'Multiculturalism in Singapore: the Way to a Harmonious Society' (2013) 25 Singapore Academy Law Journal 84. This was from his Audrey Ducroux Memorial Lecture given in 2012.

2 Ibid., 85.

3 Julia Gillard, Speech to the Multicultural Council of Australia, Parliament House Canberra, 19 September 2012. Available at: www.theage.com.au/national/ gillard-defends-nations-diversity-20120919-267d7.html\#ixzz2UHUfh6SM. 
and principles. Yet, despite this common legal heritage and a government endorsed policy of multiculturalism, only Singapore has adopted and endorsed a form of formal legal pluralism; today more aptly described as legal dualism. Muslim citizens in Singapore are legally required to apply Shari'ah personal status laws and to have family and inheritance matters arising from those laws resolved in a separate Shari'ah Court system. The Shari'ah Court operates exclusively for Singapore's Muslim population and is separately administered and fully government funded. Singapore's model of legal dualism is well accepted by the nation's Muslim and non-Muslim communities. The model is promoted as a workable, ongoing and respectful manifestation of legal coexistence based on "the mutual respect the Muslim and the non-Muslim community have for each other' ${ }^{4}$ In Australia, a different approach was taken, known as 'one law for all'. There are neither separate courts nor Islamic personal status laws enacted for or applied to Muslim Australians, nor for any other religious or ethnic group. In the Australian 'one law for all' approach, Muslims are free to adhere to Islamic law in their personal lives, but it always remains a matter of self-choice taken in accordance with one's religious conviction and personal conscience. Muslims' commitment to Islamic law is evident in their use of a wide array of informal forms of Islamic arbitration and dispute resolution to resolve any family or community matters that arise. This is accepted by Australian law provided the outcome is not in conflict with, or contrary to, it.

This chapter will provide a theoretical and practical analysis of these two distinctive approaches: the legal dualism of Singapore and the legal monism in Australia. The first section will look at the historical setting in which these approaches arose during the time of British colonisation to explain why, right from inception, a different course was chartered in each country and how that direction was affirmed at independence. The second section will consider the practical aspects of how both systems operate today though the two key life events of marriage and divorce, and the consequences for Muslims and non-Muslims in both instances. Lastly, there will be comparative analysis of philosophical basis for both approaches by highlighting the ways in which the two systems diverge today.

4 Ahmad Nizam bin Abbas, 'The Islamic Legal System in Singapore' (2012) 21(1) Pacific Rim Law and Policy Journal 163, 187. 


\section{HISTORICAL CONTEXT AND ITS CONSEQUENCES}

In the late nineteenth century, when the British arrived in Singapore and Australia, they found inhabitants whose prior settlement and control over the land was identified through terms such as 'native', 'indigenous' or 'Aboriginal' peoples. In Singapore, these were the Malays with a handful of Chinese 'living along the banks engaged in pepper and gambier planting'. ${ }^{5}$ The religion of the Malays since the fourteenth and fifteenth centuries had been Islam. The British had earlier encountered Islamic law in India when Warren Hastings, as Governor-General (1773-84), recognised its importance to Muslim Indians. He created a hybrid known as 'Anglo-Mohammadan Law' which was a compilation and later a codification of Islamic texts and practices which incorporated some aspects of English law, including concepts of case law and precedent. In this way, Islamic personal status law could be administered by British judges in India's common law courts or in separate Shari'ah Courts. Based on the experiences from India, it was not surprising that a similar pluralistic model was adopted by the British in the 1820s in colonial Singapore ${ }^{6}$ in which, depending on one's ethnicity or religion, separate legal orders for personal $\operatorname{law}^{7}$ operated. This was not just for the Malays. In addition to 'Mohammadan' law for Malays, Chinese customary law of marriage and family coexisted with the religious laws of the Hindus, Sikhs and Jews. English Christian-derived marriage and family law was of course applied to its own expatriate community. However it was of significance that in Sir Stanford Raffles' negotiations with Sultan Hussein Muhammad Shah ${ }^{8}$ for the island of Singapore, a condition was that a special legal status for Muslim Malays must be maintained. It was agreed that in all cases

5 Keong, n1, 84, 96.

6 Singapore was founded by Sir Stanford Raffles in 1819 through the British East India Company. With Penang and Malacca, Singapore became part of the Straits Settlements in 1825. In 1866 the Settlements came under the direct control of the Colonial Office in London and were disbanded after World War II. In 1946, Singapore became a Crown colony.

7 Leong Wai Kum, Elements of Family Law in Singapore (Singapore: Lexis-Nexis 2007) 885-7. The Mohammedan Marriage Ordinance of 1880 allowed for the establishment of Kathi courts.

8 Singapore was under the control of the Sultan of Johore, and Sultan Hussein was supported in that position by Raffles. On the founding of Singapore, see Kevin Y. L. Tan, 'Singapore: A Statist Legal Laboratory' in E. Ann Black and Gary F. Bell (eds), Law and Legal Institutions of Asia: Traditions, Adaptations and Innovations (Cambridge, UK: Cambridge University Press 2011) 331. 
involving Malays in ceremonies of religion, marriages and inheritance, 'the law and custom of the Malays will be respected' unless 'contrary to reason, justice or humanity'. ${ }^{9}$ From the outset, Islamic law was separately recognised and the Singaporean legal system evolved pluralistically.

In contrast, there was no Muslim presence in Australia when colonisation took place. The British could find neither a recognisable religion nor a legal system. The colonial categorisation of Australia as 'terra nullius' (land belonging to no one) ${ }^{10}$ stands in contrast to the process in Singapore and other parts of South East Asia where the British found a religion, laws and a form of governance they recognised. These discoveries enabled negotiations and treaties to be signed with the various South East Asian Sultans. There was no treaty negotiated in Australia nor was there any formal recognition of the indigenous beliefs, customary laws and dispute resolution process of the Australian Aborigines. When Captain Arthur Phillip hoisted the Union Jack at Sydney Cove in 1788 and proclaimed the continent for King George III, the Aboriginal people became subject to the laws of England and its courts. Legal monism had its genesis in this time. Although in recent decades there has been legal recognition of native title ${ }^{11}$ and special sentencing courts, known as Murri or Koori Courts, set up in some states for indigenous Australians who plead guilty to minor offences, separate legal recognition of Aboriginal laws and customs pertaining to family, inheritance and other personal status issues has never been accorded. These different historical foundations have led to a distinctive legal trajectory for both nations.

At the time when the six British colonies ${ }^{12}$ federated in 1901, the Australian Constitution omitted any recognition or acknowledgement of the first peoples of Australia. ${ }^{13}$ Although in 1901 Christians made up over

9 Cited by Noor Aisha Abdul Rahman, 'Muslim Personal Law within the Singapore Legal System: History, Prospects and Challenges' (2009) 29(1) Journal of Muslim Minority Affairs 109-126.

10 This was justified on the basis of the legal concept of terra nullius in international law. The validity of terra nullius in Australia was not considered by the High Court of Australia until 1992 in Mabo v Queensland (No.2) (1992) 175 CLR 1 .

11 The decision in Mabo v Queensland (No.2) (1992) 175 CLR 1 was given legislative effect by the Native Title Act 1993 (Cth) with the National Native Title Tribunal established to determine claimant applications.

12 New South Wales, Victoria, Queensland, South Australia, Tasmania and Western Australia.

13 Currently, there is debate on how best to redress this omission. To give recognition of Aboriginal and Torres Strait Islander peoples in the Australian 
98 per cent of the population, the Constitution did not establish Christianity or one of its denominations (for example, Church of England, Roman Catholicism or Presbyterianism) as the state religion, opting instead for a de-establishment provision. Section 116 makes it unconstitutional for any religious test to be required as a qualification for any office or public trust under the Commonwealth. The Constitution guaranteed freedom to practise one's religion. Muslims living in Australia in those early days of settlement were able to practise Islam and to establish mosques, Islamic schools and community centres. Whilst antisectarianism informed Australia's secularism ${ }^{14}$ the Australian secular system did allow each and every religion and spiritual tradition to have its own place of worship and for followers to apply voluntarily any religious law with the proviso that it did not transgress any national or state law. As a consequence, many of Australia's religions have kept alive their own religious laws especially dealing with matters of marriage, including the validity or invalidity of inter-faith marriage, and matters of divorce and the care of children. These remain internal to the religion and are quite separate from government or judicial control. Each religion, sect or faith tradition is able to establish processes to address compliance with its religious and legal requirements and to set up informal courts, boards or tribunals to deal with issues that arise. ${ }^{15}$ As adherence to Shari' ah is voluntary, Australian Muslims are able to accept or reject any decrees or rulings pertaining to Shari'ah law given by sheiks, imams or boards. Decisions are unofficial and are not legally enforceable, nor are they reviewable by Australian courts.

By contrast, Muslims in Singapore are legally required to have personal status matters resolved by the Shari'ah Court and in accordance with the Administration of Muslim Law Act 1966 (Cap 3) ${ }^{16}$ (hereinafter AMLA). This separate avenue was entrenched and well accepted at the time of Singapore's independence in 1965. AMLA replaced the Muslims' Ordinance (1957) which was a revision of the earlier Mohammadan

Constitution is seen as an important step towards building a nation based on mutual respect and understanding.

14 These views are expanded by Malcolm Voyce and Adam Possamai, 'Legal Pluralism, Family Personal Laws and the Rejection of Shari'ah in Australia: A Case of Multiple or Clashing Modernities' (2011) 7 Democracy and Security 339, 343.

15 The Roman Catholic Church has ecclesiastical courts, Jews have the Beth Din, a rabbinical court, and Muslims have Shari'ah councils (majlis).

16 Administration of Muslim Law Act 1966, Act 27 of 1966, 2009 Rev. Ed. Sing. [hereinafter AMLA]. 
Marriage Ordinance (1880), which was the first legislative enactment of the laws and regulations to be exclusively applied to Muslims in Singapore. From 1961, all non-Muslims in Singapore - whether Hindu, Buddhist, Christian or Sikh - were governed by the Women's Charter. It was called a Charter not an Act because it was to be the Charter for women's rights and has been credited with changing the family law landscape for non-Muslims through its commitment to monogamy and by working towards the legal and economic equality of married women. ${ }^{17}$ It ended Singapore's era of legal pluralism in favour of dualism, as the only exception to this law was for persons of the Islamic faith. Prior to independence, Singapore also had established courts with exclusive jurisdiction over Muslims which from 1955 onwards were designated as Shari'ah Courts. These continued post-independence. In addition, Singapore had had many decades of separate administrative bodies for Muslims. The Muslim Advisory Board was established in 1946 to advise the government on Muslim issues and matters pertaining to Islam. Under AMLA these functions were subsumed and strengthened by the Majlis Ugama Islam Singapura (hereinafter MUIS). To legitimise a separate legal regime for its Muslim citizens, the Constitution of Singapore was drafted to recognise Malays as 'the indigenous people of Singapore', ${ }^{18}$ thus justifying the grant of special legal status to Muslims. In so doing, it also honoured the original agreement between Raffles and Sultan Hussein Muhammad Shah. Section 153 of the Constitution provides that the legislature can make laws 'regulating Muslim religious affairs' and can constitute a Council to 'advise the President in matters relating to the Muslim religion'. Section 12 of the Constitution excludes the regulation of Muslim personal law from the constitutional guarantees to its citizens of 'equality before the law' and 'equal protection'.

Due to the accumulation of these precursors, Ahmad Nizam believes that at the time of independence in 1965, the right for Muslims in Singapore to adhere to Islamic law was so entrenched that AMLA merely facilitated rather than created 'a new jurisprudence of law'. ${ }^{19}$ As AMLA was applied by the Shari'ah Court, the family law system of Singapore became a dual, not plural system. It was based on religious identification only in so far as Muslim or non-Muslim identity.

17 Chan Wing Cheong, Leong Wai Kum and Debbie Ong Siew Ling, 'Editorial' (2011) July Singapore Journal of Legal Studies x-xii.

18 Constitution section 152.

19 Ahmad Nizam bin Abbas, 'Overview of Islamic Judicial Structure in Singapore', unpublished. 


\section{PRACTICAL CONSEQUENCES OF LEGAL DUALISM AND MONISM IN THE APPLICATION OF SHARI'AH FAMILY LAW TODAY IN AUSTRALIA AND SINGAPORE}

\section{A. Marriage}

When Muslims marry, ${ }^{20}$ most will do so in accordance with the Shari'ah. In approaching important life events, Muslims, even non-observant ones, seek to 'get it right' by using traditional practices that accord with their religious and moral obligations. ${ }^{21}$ In both Singapore and Australia, Muslim couples marrying in accordance with Islam will need to meet the form requirements of a valid Islamic marriage which include a nikah (marriage contract) with offer and acceptance, witnesses and maskahwin/ mahr (dowry) provisions; the contract may also contain valid contractual taklik (conditions). The conditions were included to give certainty and security to a wife, and her maskahwin/mahr was the traditional legal means for protecting and empowering her for the duration of the marriage. It was an important resource by which a wife could finance her post-marriage period of life. Also, for the marriage to be valid in Islamic law, it must not violate any of the permanent or temporary prohibitions laid down by the Shari' ah. ${ }^{22}$

For Singaporean Muslims, the specific requirements and form for marriage are found in AMLA augmented by local Malay customs and traditions. In a dual legal system, the applicable marriage law depends on the religion of the parties to the marriage. For Muslims the laws on marriage are contained in Part VI of AMLA, whilst for all other Singaporeans these laws are in the Women's Charter. ${ }^{23}$ In the Charter, the marriageable age is 21 years although 18-, 19- and 20-year-olds can marry with parental consent; in AMLA, the marriageable age is now

20 Marriage is seen as desirable, even an obligation on Muslims.

21 Julie Macfarlane, 'Islamic Divorce in North America' in Anna C. Korteweg and Jennifer A. Selby (eds), Debating Sharia: Islam, Gender Politics and Family Law Arbitration (Toronto: University of Toronto 2012) 40. It notes that the number of North America Muslims who marry with a nikah is far higher than those who attend prayers or consider themselves to be observant.

22 Ann Black, Hossein Esmaeili and Nadirsyah Hosen, Modern Perspectives on Islamic Law (Cheltenham: Edward Elgar 2013) 111-21.

23 Cap 353, 2009 Rev. Ed. Sing. 
18 years. ${ }^{24}$ One of the differences between the two laws is that AMLA specifies and codifies the role of the wali, who is defined in AMLA section 2 as 'the lawful guardian according to Muslim law for purposes of marriage of a woman who is to be married'. In practice, the wali is the bride's birth father, her paternal grandfather, brother, paternal uncle or any male relative from her paternal side. ${ }^{25}$ AMLA has provisions, however, for a kadi (Islamic judge) to intervene in cases where a woman has no wali, or where the wali refuses to consent to the marriage. ${ }^{26}$ Where the bride is the only Muslim convert in her family, a wali is not required. Another significant point of differentiation is that polygamous marriages are lawful for Muslim men in Singapore (the maximum is four wives at a time), although an application for each additional wife must be made to the kadi, who will conduct interviews prior to allowing or disallowing the marriage. ${ }^{27}$ For Singapore's non-Muslims, polygamy is prohibited by section 4 of the Charter, rendering any subsequent marriage void.

Registration of marriage also comes under a dual system. The Registry of Muslim Marriages (ROMM) has exclusive jurisdiction to register marriages where both parties are Muslim, ${ }^{28}$ whilst the Registry of Marriages (ROM) registers all other Singaporean marriages including marriages between a Muslim and a non-Muslim. This is the case even where the non-Muslim woman is a Christian or Jew. In some schools and traditions of Islam, such a marriage could be lawful because of the kitabiyah (person of the Book) ${ }^{29}$ categorisation. For Shia and Muslims who adhere to the Hanafi school of Islam, marriage between a Muslim man and kitabiyah woman is lawful, ${ }^{30}$ although it is generally regarded as undesirable. However, Singapore follows the Shafi'i school in this and most matters. Shafi'i employs a narrow interpretation which requires the woman to establish

24 Amended in 2009 from 16 years by section 19 of the Administration of Muslim Law (Amendment) Act 2008 (Act 29 of 2008).

25 http://app.romm.gov.sg/about_marriage/romm_wali.asp.

26 Section 95, Administration of Muslim Law Act 1966, Act 27 of 1966, 2009 Rev. Ed. Sing.

27 http://app.romm.gov.sg/about_marriage/romm_polygyny.asp.

28 Section 89, Administration of Muslim Law Act 1966, Act 27 of 1966, 2009 Rev. Ed. Sing.

29 The term the 'book' refers to revealed law through the lawgivers in the Abrahamic tradition. See generally Maznah Mohamad, 'Islam and Family Legal Contests in Malaysia: Hegemonizing Ethnic over Gender and Civil Rights' Asia Research Institute Working Paper series No.109, The National University of Singapore, 8 .

30 The Prophet married a Christian and also a Jewish woman. 
she is a descendant from a lineage that was Christian before the time of the Prophet Muhammad, or Jewish before the time of the Prophet Isa conditions that are almost impossible to fulfil. Consequentially, in practical terms this amounts to a de facto not de jure prohibition on this type of inter-faith marriage. For this reason, the marriage would need to be registered under ROM, unless there was a prior conversion to Islam.

In secular Australia, there are no equivalent restrictions on religious grounds on whom one can marry. Under the Marriage Act 1961 (Cth), marriages between Muslims and non-Muslims present no legal obstacle; however, as most Muslims prefer to marry within their faith tradition, imams who conduct Islamic marriage ceremonies can refuse to marry the couple until the non-Muslim party converts. For this reason it is not uncommon for a conversion ceremony to precede a marriage ceremony, although distinguishing between the two events can be difficult in some cases and require court determination. ${ }^{31}$ Also, where one party is not Muslim, this fact may be kept secret from both the imam and the Muslim spouse's family and friends. When there is deception of this type, it can unravel later, as was seen in $H v H$ [2003] FMCAfam 31 where the imam and the bride's Lebanese family were unaware that the man she was marrying in the Islamic ceremony was a Maronite Christian.

Australia's Marriage Act 1961 (Cth) is accommodating of Islamic marriage. It provides that Islamic marriage ceremonies can be performed and the marriage registered with the relevant state government office for births, deaths and marriages. However, to be registered, the marriage must meet the requirements of the Act including that the parties are of marriageable age and have freely given consent, there is an absence of consanguinity and the ceremony must have been conducted by a recognised marriage celebrant or minister of religion. For Muslims this will usually be an imam or sheik from their mosque. The result is that marriages between Muslims can be simultaneously valid under Islamic law and Australian law. Some Muslims will choose to just have the marriage contract (nikah) and an Islamic ceremony making their union a lawful Islamic marriage without registering the marriage in accordance with the Australian legislation. There are several reasons for this, ranging

31 Wold v Kleppier [2009] FamCA 178 [note the names of the parties in Family Court cases are a pseudonym given by the court to protect identification]. The Court had to decide whether a ceremony performed by an Imam was an Islamic marriage ceremony or merely one converting the woman with whom he lived to Islam. Kleppir, the husband, claimed that the ceremony was a conversion to Islam ceremony whilst the wife claimed that it was a marriage. 
from a conscious rejection of secular requirements in deference to a purely religious union (nikah) to inadvertence or lack of knowledge of the law. Non-registration can occur because the couple plan to return to a Muslim nation where only the Islamic nikah will have application, rendering the Australian certification obsolete. It can also occur as an oversight or from an erroneous belief that the Islamic marriage is automatically a state marriage, or because one or both of the spouses believe that the marriage is going to be registered but the imam fails to do so. ${ }^{32}$ In some cases it is because the person who performs the ceremony is not qualified or registered as a marriage celebrant, ${ }^{33}$ or because the marriage does not meet Australian requirements for a lawful marriage. If one or both are under the lawful age for marriage (which is 18 years) $)^{34}$ it will be unlawful and also an offence under section 95 of the Marriage Act 1961 (Cth). ${ }^{35}$ Imams have indicated that with underage marriages, they encourage the couple to register the marriage when both attain lawful marriage age. If the marriage is polygamous, it is also unlawful and constitutes the criminal offence of bigamy. ${ }^{36}$ There is no accurate way of knowing the extent of underage and polygamous marriages. Sheikh Chami of Lakemba Mosque argues that it is not difficult for a man wanting to take a second wife to find 'someone' with Muslim credentials to approve it, on the basis that 'if I don't want to do it, another imam will do it' 37

32 Oltman \& Harper (No.2) [2010] FamCA 1360.

33 Marriage Act 1961 (Cth) section 5(a) a minister of religion registered under Subdivision A of Division 1 of Part IV; or (b) a person authorised to solemnise marriages by virtue of Subdivision B of Division 1 of Part IV; or (c) a marriage celebrant.

34 Marriage Act 1961 (Cth) section 1: 'Subject to section 12, a person is of marriageable age if the person has attained the age of 18 years.' Section 12 allows a person who has attained the age of 16 years but has not attained the age of 18 years to apply to a Judge or magistrate for an order authorising him or her to marry a particular person of marriageable age. The judge will require the circumstances of the case to be exceptional and unusual as to justify the making of the order.

35 It is a defence to a prosecution under section 95 for the defendant to prove that he or she believed on reasonable grounds that the person with whom he or she went through the form or ceremony of marriage was of marriageable age, or had previously been married, or had the consent of the court to do so in accordance with the Act.

36 Marriage Act 1961 (Cth) section 94.

37 Quoted in an interview with Sally Neighbour, in 'The Way to the Watering Hole: Sharia Law', The Monthly, December 2010, www.themonthly. com.au/issue/2010/december/1294083136/sally-neighbour/way-watering-hole. 
Some Muslim marriages may not be registered because in Australia they would be deemed a 'forced' or 'servile' marriage. These are distinct from arranged or facilitated marriages, which are lawful as both parties have given full and informed consent. ${ }^{38}$ Whilst it is more typical for the victim of a forced marriage to be taken overseas to wed under the national law of another country, marriages where there has been physical, emotional or financial duress or deception do take place in Australia. Forced marriage is, of course, contrary to Islamic law but Muslim sheiks and Imams do officiate over such marriages, possibly in the misguided belief that the Muslim parents who seek these are 'protecting their child or preserving cultural or religious traditions'. ${ }^{39}$ The Australian government believes that cases of forced marriage are widely under-reported and in 2011-12 conducted an enquiry into the problem. ${ }^{40}$ The Crimes Legislation Amendment (Slavery, Slavery-like Conditions and People Trafficking) Act was enacted in 2013 and criminalizes forced marriage, imposing a seven-year maximum imprisonment term for any person who attempts to force a vulnerable person into marriage. ${ }^{41}$ Giving evidence in the case of Wold $v$ Kleppier ([2009] FamCA 178, the imam who performed the ceremony but did not register the Islamic marriage explained that Islamic marriages are 'very, very quick to perform' as the one-month notice period of intention to marry is not required, ${ }^{42}$ nor are birth certificates and other forms of identity required. ${ }^{43} \mathrm{~A}$ final ground for not registering an Islamic marriage is that it will allow a husband a quicker and easier divorce by talak/talaq divorce (unilateral right of a

38 Such marriages performed under duress also occur in mainly South Asian and Middle-Eastern ethnic communities, and are not confined to Muslim adherents. Coptic and some other Christian sects, Hindu and 'traveller' families also engage in the practice.

39 Attorney-General's Department, Discussion Paper: Forced and Servile Marriages, www.ag.gov.au/Consultations/Documents/Consultationonforcedand servilemarriage/Discussion $\% 20$ Paper $\% 20$ for $\% 20$ Public $\% 20$ Release $\% 20$ forced $\%$ 20 and $\% 20$ servile $\% 20$ marriage.pdf.

40 The report estimated that there are 1000 forced marriages occurring annually.

41 The Crimes Legislation Amendment (Slavery, Slavery-like Conditions and People Trafficking) Bill 2012 was introduced on 12 April 2012 and passed by both Houses of Parliament in February 2013.

42 The Marriage Act 1961 (Cth) section 42 requires written notice of the intended marriage to be received not later than one month before the date of the marriage.

43 Wold v Kleppier [2009] FamCA 178: para 30. 
husband to divorce by pronouncement) should he want to end the marriage at any time.

Another difference between the two countries is that in Australia, a couple also has the choice to cohabit without marrying, as a de facto couple, in which case they will receive legal protections akin to a married couple. The latter attracts no penalty, whereas in Singapore such cohabitation could be a criminal offence (section 134 AMLA), attracting possible fines and/or imprisonment. AMLA also makes it an offence to entice an unmarried woman away from her wali (male guardian). However, as Singapore does not have religious police, it is generally acknowledged that this provision is rarely enforced. However, it acts as a deterrent and educative principle. Furthermore, in 2017, Australia enacted legislation to allow same-sex or homosexual marriage under the Marriage Amendment (Definition and Religious Freedoms) Act, and no longer has any criminal sanctions for homosexual acts between consenting adults (over the age of 18 years). Whilst no one has been recently prosecuted, section 377A of Singapore's Penal Code does make acts of 'gross indecency' between men a crime, with a two-year imprisonment term. The constitutionality of this section was upheld by Singapore's High Court in 2013.

In summary, in Australia's 'one law for all' approach there is one Act regulating marriage with religious affiliation playing no role in marriage validity or its registration. Complete freedom is given to the individual to follow his or her religious or non-religious traditions for marriage, which, provided there is compliance with each component of the Act, can be lawfully registered. In Singapore, the main difference is that there is a dual system with separate legal pathways provided for Muslims and other Singaporeans. Muslim marriage is governed exclusively by AMLA with separate registration, from which a range of legal consequences flow should the marriage end by divorce or when one of the spouses dies.

Who is a Muslim for the purposes of the Women's Charter and for the application of AMLA? Section 2 of AMLA gives little guidance, as it provides simply that a Muslim is 'a person who professes the religion of Islam' and states that the court's jurisdiction is for actions and proceedings in which 'all the parties are Muslim or where the parties were married under the provisions of Muslim law'. ${ }^{44}$ There is acceptance that a child born to a Muslim parent is by birth Muslim, as is a person who formally converts to Islam and registers the conversion with ROMM.

44 Section 55(2), Administration of Muslim Law Act 1966, Act 27 of 1966, 2009 Rev. Ed. Sing. 
Although the issue of 'who is Muslim' does not frequently arise, jurisdiction can be relevant in cases of mixed religious marriages or in situations of conversion, whether into or out of, Islam especially for marriage validity ${ }^{45}$ and for inheritance distribution, ${ }^{46}$ as the estate of a Muslim must be distributed in accordance with Islamic inheritance laws. ${ }^{47}$

\section{B. Divorce}

Islamic law has always allowed for divorce by either the husband or the wife. It has been widely disliked but the message in the Quran is clear: couples need not stay in unhappy or destructive marriages. Instead they should part 'with kindness'. The avenues for divorce differ for husbands and wives. As already mentioned, husbands can divorce by talak/talaq (pronouncement), ${ }^{48}$ and there are several forms of divorce generally accepted as available to wives including mubarat, mutual agreement; taklik/ta'liq, breach of a marriage condition; talaq-i-tafwid, a delegated divorce; fasakh, annulment or fault divorce; khuluk/khula, no-fault divorce but where a wife dislikes her husband and returns her maskahwin/mahr; dharar, dissolution because of the husband's cruelty; and divorce by conversion of one spouse to another religion.

In keeping with its 'one law for all' commitment, Australia also takes a monist stance on divorce with one law, the Family Law Act 1975 (Cth) governing divorce and all ancillary matter including the care of children, property and financial issues flowing from the divorce. Under s48 of the Family Law Act (Cth), the only ground for divorce in Australia is 'irretrievable' breakdown of the marriage proven by 12 months' separation. Fault is irrelevant. As the law applies equally with the same procedure required for husbands and for wives, and as the court is unconcerned about the cause of the marriage breakdown, both dimensions place Australian divorce law at odds with the principles and processes of Islamic divorce. Because of the gender complexity in Islamic divorce, there cannot be simultaneously a valid Australian (that

45 Noor Azizan bte Colony (alias Noor Azizan bte Mohammad Noor) v Tan Lip Chin (alias Izak Tan) [2006] 3 Singapore Law Reports 707.

46 Re Mohammad Said Nabi, decd (1965) 31 Malayan Law Journal 121.

47 Sections 111 and 112 of Administration of Muslim Law Act 1966, Act 27 of 1966, 2009 Rev. Ed. Sing.

48 This term and the divorce terms that follow are transliterated in Singapore as talak, whilst talaq is more commonly used in Australia. For this reason, both have been included in this section. 
is, secular) divorce which also serves as an Islamic one. For example, a talak/talaq divorce proclaimed by a husband in Australia has no formal legal status, although he may hold it to be lawful under Islam and it may be seen as such in the eyes of his family and the Muslim community to which he belongs, including its religious leaders. Although talak/talaq has no legal consequences under Australian law, it may be used to mark the commencement of the required 12-month separation period needed to establish 'irretrievable' breakdown of the marriage. In the same way, a divorce decree (absolute) under Australian secular law will not generally be recognised as also ending the religious Islamic marriage.

However, as with marriage, a Muslim couple can comply with both Shari'ah and Australian divorce law, but they are two separate events. The Australian divorce is overseen by the Family Law Act and the Family Courts, but Islamic (or other religious) divorce is relegated to an informal and unofficial regulatory process governed by the rules and processes of the religion itself.

Without a formal Shari'ah Court, a wife seeking a Shari'ah divorce in Australia has to find a person or organisation that she believes can grant her a divorce in accordance with Islamic law. This is not always easy, especially for recent immigrants, or for couples with tenuous links to a mosque or a Muslim community. However, obtaining an Islamic divorce remains of considerable importance. Krayem Ghena explains that 'regardless of their religiosity, even if they have never walked into a mosque in their lives, and don't really pray or do any outwardly religious things, when it comes to marriage and divorce they think it's important to go to a mosque or imam' ${ }^{49}$ In the Australian context, much will hinge on the imam or group of scholars to whom the wife turns. As there are no religious qualifications prescribed by the government, nor are religious functionaries appointed by the government (unlike in Singapore), it is a system resting on self-assertion of expertise or Muslim community recognition of a person's religious authority and standing. The men assuming this role are usually sheikhs or imams, but it could also be undertaken by an individual Shari'ah scholar or group of scholars or imams (majlis ulama) who simply put themselves forward as sufficiently learned, pious or authoritative to make family law determinations, especially for the ethnic community with which they are aligned. In determining issues of Islamic divorce they may apply modernist interpretations on matters such as polygamy, divorce, maskahwin/mahr rulings, property settlement and child custody, or they may adhere to

49 Krayem Ghena quoted in Sally Neighbour, above n37. 
patriarchal, conservative and textualist interpretations that are found in the more conservative parts of the Muslim world. This increases the likelihood of inconsistent outcomes, ${ }^{50}$ and also gives rise to concerns of unaccountability and the possibility of error or bias. One tangible consequence is the practice of Imam shopping. When it is known, for example, that certain imams will not grant a khuluk/khula divorce (divorce by redemption where the wife forgoes her mahr to buy her way out of the marriage) unless the husband first agrees to the divorce, ${ }^{51}$ a wife may seek an imam with a more liberal interpretation. Some imams are known to give greater veracity to a husband's statement of facts and accept his over his wife's in cases of fasakh (where a wife seeks divorce based on fault). When a conservative approach favours the husband in divorce cases, it can leave Muslim women disadvantaged and vulnerable. This is especially true for recent migrants whose English is limited, and who have little knowledge of additional avenues or contacts outside their immediate Muslim community. The phenomenon known as 'limping' marriages, where a secular divorce is given or is available to a wife, but a religious one is denied, is well documented in Australia ${ }^{52}$ and also in the United Kingdom. ${ }^{53}$ What isn't known is the number of wives in that

50 Inconsistency may be simply a reflection of the diversity within the Australian Muslim population and a confirmation of the diversity of interpretations within 'Islam' itself.

51 There are a range of interpretations on this. In khula the wife requests divorce and in return provides her husband with compensation, which is usually the return of part or all of her mahr, or if deferred, to forego her rights to it, along with rights to maintenance during her iddah (three-month waiting period before a divorce becomes irrevocable). The divorce is irrevocable. If the husband agrees, he will pronounce talaq on those terms, or a court will order him to do so once the court has settled the amount of the compensation payable by the wife. There is debate on the matter of whether the husband must agree to this and whether his lack of consent negates khula. Jurisprudence developed over many centuries in which the dominant position was that a grant of khula was contingent upon the husband's consent. However, in recent times when this issue has been revisited, this fetter has often been removed.

52 Family Law Council of Australia, Report on Cultural Community Divorce and the Family Law Act 1975 (2001) 4 (Executive Summary 17).

53 Law Commission UK (Law Com. No.48) Family Law: Report of Jurisdiction in Matrimonial Causes (1972); Ishan Yilmaz, 'Muslim Alternative Dispute Resolution and Neo-Ijtihad' (2003) 2, 1 Alternatives 1; Muslim Arbitration Tribunal, Family Dispute Cases: www.matribunal.com/cases_faimly.html. Also in secular Turkey, see Ishan Yilmaz, 'Non-Recognition of Post-modern Turkish Socio-political Reality and the Predicament of Women' (2003) 30(1) British Journal of Middle Eastern Studies 25-41. 
position. Macfarlane estimates that 20 per cent of Muslim women in Canada who seek a Shari'ah-sanctioned divorce do not obtain one. ${ }^{54}$ President of the Australian Federation of Islamic Councils Iqbal Patel sees limping marriages as a significant issue which warrants government intervention to deal with 'the difficulties some divorced Muslim women experienced in persuading their former husbands to grant them a religious divorce. If that doesn't happen, she is in limbo - she cannot move on.' 55

In Singapore, limping marriages do not arise. As there is no avenue for a Muslim to go the civil court and use the divorce procedures under the Charter, it is not possible to have a secular divorce and be denied a religious one. If you married under AMLA then you are required to divorce under AMLA. As with marriage, in Singapore there is a dual system for divorce. One's divorce pathway depends solely on religious affiliation. For Muslims, only the Shari'ah Court has authority to hear and determine a divorce application. AMLA recognises many of the classic Shari'ah divorce avenues: talak/talaq for the husband, although the court has the power to appoint arbitrators to bring out a reconciliation (section 50), but as the divorce takes effect from the time of pronouncement this is not a significant limitation. Referral for arbitration and counselling can also be ordered when a wife requests divorce by khuluk/khula (section 46), taklik/ta'liq (section 48) and fasakh (section 49). Whilst the grounds for fasakh are quite specific, the law on divorce in AMLA is not a comprehensive codification and the court's general jurisdiction to apply Muslim law continues, which can be varied where applicable by 'Malay custom'. ${ }^{56}$ The court therefore can turn to primary sources of law, the Quran and Sunnah, as well as the writings of classic jurists and scholars for elaboration and interpretation. ${ }^{57}$ In this way the court has the jurisprudential licence to invoke interpretations of Islamic family law that resonate with family life in contemporary Singapore. Yet Abdul Rahman has found that the court accepts and does not question what it sees as an immutable body of divine and absolute legal rules, but

54 Macfarlane, n21, 60.

55 Chris Merritt, 'It Was a Mistake to Mention Sharia Law, Admits Islamic Leader' The Australian, 17 June 2011. Also, Ismael Essof, 'Divorce in Australia: from an Islamic Perspective' (2011) 36(3) Alternative Law Journal 182-6.

56 Section 35(3) Administration of Muslim Law Act 1966, Act 27 of 1966, 2009 Rev. Ed. Sing.

57 Noor Aisha bte Abdul Rahman, 'Traditionalism and its Impact on the Administration of Justice: The Case of the Shari'ah Court of Singapore' (2006) 5(3) Inter-Asia Cultural Studies 415, 432. 
what she describes as 'the rich and diverse body of juristic thought and legal traditions are of little interest or concern'. ${ }^{58}$ Whilst AMLA could allow for assimilation of more progressive and egalitarian legal opinions on many aspects of family law, the court in Singapore instinctively adopts what has been described as a traditionalist stance. This is particularly evident in divorce cases, where the Shari'ah Court in Singapore upholds the conservative view that divorce is the "exclusive preserve of the husband who has an unfettered right to pronounce talaq and thereby terminate his marriage without cause'. ${ }^{59}$ Abdul Rahman also found that the court makes divorce applications by women procedurally onerous and resists decreeing divorces initiated by wives. ${ }^{60}$ Fasakh, for example, was found to be confined to a few cases of apostasy and insanity, and the referral to arbitrators appeared merely to lengthen the process, with the added disincentive that further financial costs would be incurred. ${ }^{61}$

The Shari'ah Court's exclusive power to hear and make an order on divorce does not extend to determining all the legal issues that may arise in a divorce case. Matters of spousal maintenance or whether a protection order should be issued must be remitted to the civil court. In some matters the courts have concurrent jurisdiction. Whilst a Muslim couple must have their divorce heard in the Shari'ah Court, applications for child custody, access and distribution of matrimonial property can be made to 'any court', which enables a Muslim party during or after divorce proceedings in the Shari'ah Court to make an ancillary application to the civil Family Court where the civil law will be applied. ${ }^{62}$ AMLA requires this to be with the consent of the parties and with the leave of the Shari'ah Court. ${ }^{63}$ Although adoptions fall under the jurisdiction of the civil family court, ${ }^{64}$ the court takes into account Islamic principles on adoption - for example, to allow the child to keep the name of her birth parents and not that of the adoptive family (Abdul Rahman 2004: 416). Also as the Shari'ah Court lacks powers of enforcement, its orders for

$\begin{array}{ll}58 & \text { Ibid., } 417 . \\ 59 & \text { Ibid., } 418 . \\ 60 & \text { Ibid., } 422 . \\ 61 & \text { Ibid., } 425 . \\ 62 & \text { Section 17A(2) Supreme Court of Judicature Act, Cap 322, } 2009 \text { Rev. Ed. }\end{array}$ Sing.

Section 35A, Administration of Muslim Law Act 1966, Act 27 of 1966, 2009 Rev. Ed. Sing.; Supreme Court of Judicature Act, Cap 322, 2009 Rev. Ed. Sing. section 17.

64 Adoption of Children Act, Cap 4, and generally see bin Abbas 2012: 174. 
mutaah (compensation), ${ }^{65}$ marriage expenses, custody and property division are enforceable (section 53) but not reviewable by the civil court. They are enforced as if they were orders of the District Court. It means that in many areas of family law there is a shared jurisdictional arrangement between the religious and the civil court. This gives rise to one of two views: it is either a working court partnership or a system made notoriously complex.

\section{REFLECTIONS ON MULTICULTURALISM: CONVERGENCE AND DIVERGENCE IN AUSTRALIA AND SINGAPORE}

As outlined above, a colonial legacy has meant different practical consequences for Singapore's half a million Muslims than for Australia's Muslims. Both legal systems seek to provide just and fair family and personal law outcomes for all their citizens, but have taken different paths for achieving this goal. In managing its racially and religiously diverse society, the key in Singapore, as elsewhere in South East Asia, is 'that a well-functioning civil society is not nurtured by enforced uniformity, but by tolerance and mutual respect for different racial and religious groups'. ${ }^{66}$ If a minority ethnic or religious group feels it is protected by its own laws and has a distinctive place in the legal system, this will 'solidify their commitment to the state and enable them to focus on what is shared, rather than what divides'. ${ }^{67}$ For its culturally diverse population, Australia advocates multiculturalism in which that diversity is respected through the 'unifying principles of Australian values, identity and citizenship', but within the existing 'framework of Australian law: it is not a platform for legal pluralism based on religion, culture or ethnicity'. ${ }^{68}$ To this end the law must give sufficient scope for people to 'arrange their private affairs according to their own beliefs', providing

\footnotetext{
65 Payment of compensation to a woman divorced without fault.

66 Keong, n1, 84, 96.

67 Li-ann Thio, 'Constitutional Accommodation of the Rights of Ethnic and Religious Minorities in Plural Democracies: Lessons and cautionary tales from South-east Asia' (2010) 22 Pace International Law Review 43, 49.

68 Parliament of the Commonwealth of Australia: Joint Standing Committee on Migration, Inquiry into Migration and Multiculturalism in Australia, March 2013, ix.
} 
that this does not conflict with 'obligations enacted by the Australian, and state, Parliaments'. ${ }^{69}$

These divergent views on multiculturalism have meant that the role of Shari'ah law plays out in distinctive ways in each nation. These will now be considered from a comparative perspective, highlighting points of divergence.

\section{A. Indigenous Peoples versus Immigrants}

In recognising Malays as the first people of Singapore, the Constitution provides a justification for Islam and Islamic law, to be differentiated and applied separately from the Women's Charter which governs most Singaporeans. The same rationale does not apply in Australia as Australia's indigenous people have the same family law applied, as do all Australians regardless of race or religion. As the spiritual traditions of Aboriginal and Torres Strait Islanders (the first peoples of the continent) receive neither legal priority nor Constitutional recognition, it is more challenging to advocate for another sector of the community to be given special legal status, especially when they are more recent immigrants. El Matrah rejects as 'unethical' the frequently made comparison equating the rights of indigenous Australians with those of Muslim Australians. She writes that Muslims were 'part of the process that dispossessed indigenous Australians', so indigenous entitlements are beyond 'anything a migrant community should appropriately expect'. ${ }^{70}$ Additionally, Singapore's dual system was also a continuation of the legal arrangement established in the early nineteenth century; not only does this give it popular acceptance, but also its proven track record is reassuring for non-Muslims. Australians look at the application of Shari' ah law in some other parts of the Muslim world with concern, and are apprehensive about what it could mean for Australia. This is not confined to the non-Muslim population, as some Muslims migrated to Australia willingly leaving behind some components of Shari'ah law that they believed impacted in negative ways upon their lives. It is conceptually more challenging to win support in a democracy for transplanting a new and separate system of family law for Muslims, when many Australians have little knowledge of Islam. Most if not all Muslims who migrate to Australia do so in the knowledge that it is a secular nation. In Singapore it is known that Shari'ah law will be applied to Muslims.

69 Ibid.

70 Joumanah El Matrah, 'A Sharia Tribunal is a Contradiction of Islam' The Age, 20 October 2009. 


\section{B. Community Acceptance versus Community Concerns}

The longevity of legal pluralism and Constitutional protections afforded to persons of the Islamic faith in Singapore, have meant that having a religious court and different set of family laws for Muslims is accepted and rarely criticised, although though there is acknowledgement by many Singaporeans that this dichotomy remains 'very sensitive'. Ahmad Nizam Abbas, a lawyer, reflects the commonly expressed sentiment that the dual system works for the benefit of Muslim Singaporeans, describing the requirement to use the Shari' ah system as an 'honour' or 'privilege' given only to Muslims, ${ }^{71}$ and noting that the Shari'ah system is becoming increasingly more professional in ensuring fairness and justice. ${ }^{72}$ Leong Wai Kum, Professor of Law, sees Singapore's dual court system as problematic. He argues that in resolving family law disputes, 'apparent and real conflicts do crop up' which cannot be resolved by 'reference to a simple separation' of jurisdiction of the two court systems. ${ }^{73} \mathrm{He}$ concludes that as such, conflicts are 'notoriously difficult' to resolve and he awaits 'the eventual integration of the entire family law in Singapore to regulate all Singaporeans' ${ }^{74}$ Abdul Rahman also identifies 'significant problems'75 in the current system but unlike Professor Leong, she does not favour cessation of the dual system but advocates for greater jurisprudential and legislative reform of the Shari'ah system. The problems that she identifies occur because the 'substantive law on marriage, divorce and ancillary issues is not comprehensively codified' in AMLA, which leaves the interpretation of Shari'ah family law with the judges of the court and with MUIS. She feels the initial spirit of the framers of AMLA, which was attuned to the contemporary needs of women, has been eroded by traditionalism, which she cites as a 'dogmatic attitude that clings firmly to old ways, resisting innovations or accepting them only unwillingly'. ${ }^{76}$ This is significant as Muslims are restricted from accessing the civil adjudicative forum for family law matters.

\footnotetext{
71 Abbas, n4, 163.

72 Ibid., 187.

73 Kum, n7, 903 with case examples of jurisdictional conflict given at 903-16.

74 Ibid., 918.

75 Rahman, n57, 415, 416.

76 This is the definition given by Karl Mannheim cited in Rahman, n57, 415, 416. Robert Towler defines it as a "style of religious belief whose essence is to cherish the entire tradition received as sacred such that if any part is threatened or called into question, it is the whole pattern which is put at risk' in Towler, The Need for Certainty: a Sociological Study of Conventional Religion.
} 
In Australia, there is general acceptance of the 'one law for all' approach. There is a level of consensus that social cohesion and unity is best achieved through a single legal order, not multiple ones, to protect 'the principles of equality, legal security, legality, and political unity' ${ }^{77}$ In March 2013, the Australian government re-committed the nation to this approach by endorsing the recommendation of its Parliamentary Inquiry into Migration and Multiculturalism in Australia 'not [to] support legal pluralism'. ${ }^{78}$ Instead, the government promotes the 'message that multiculturalism entails both respect for cultural diversity and a commitment to the framework of Australian laws and values which underpin social cohesion'79 (italics added). The Report specifically addressed Islamic law in the context of submissions made to it by Muslim organisations in support of Shari'ah Courts or tribunals, affirming that the 'Australian Government has consistently stated that implementation of Shari'ah law in not being contemplated' ${ }^{80}$ The Inquiry called for submissions. Of the 513 submissions made, 212 raised concerns about Islam in Australia, specifically the levels of ethnic separatism and ghettoization, with 113 objecting to the possibility of introducing legal pluralism to accommodate the requirements of Shari'ah law. Submissions from Muslim groups were also divided on the role for Shari'ah law in Australia. Iqbal Patel, representing AFIC as its President, submitted that 'multiculturalism should lead to legal pluralism', arguing that conflicts should be resolved according to the law and traditions of one's own religion. ${ }^{81}$ The AFIC submission challenged Australia's policy of multiculturalism on the ground that by limiting it to culture, religion and language and not extending it to encompass law, Australia was treating Muslims as 'second class citizens' by requiring them to live 'under one law: Western law'. He reasoned that Shari'ah was not immutable but adaptable, and it was possible to have a moderate form that could coexist

77 Daniel Bonilla Maldonado, 'Extralegal Property, Legal Monism, and Pluralism' Yale Law Electronic Resource site: www.law.yale.edu/documents/pdf/ sela/Bonilla.pdf.

78 Parliament of the Commonwealth of Australia: Joint Standing Committee on Migration, Inquiry into Migration and Multiculturalism in Australia, March 2013, 85: www.aph.gov.au/Parliamentary_Business/Committees/House_of_ Representatives_Committees?url=mig/multiculturalism/report.htm.

79 Ibid.

80 Parliament of the Commonwealth of Australia: Joint Standing Committee on Migration, Inquiry into Migration and Multiculturalism in Australia, March 2013, 67.

81 Australia Federation of Islamic Councils; Submission 81: 'Embracing Australian Values - Maintaining the Right to be Different'. 
with the Australian legal system through a concept of 'twin tolerations' .82 However, other submissions from Muslim organisations did not advocate for either Shari' ah Courts or legal pluralism, noting that 'the overwhelming majority of Australian Muslims want nothing more than to get on with their lives and make meaningful contributions' to Australia. ${ }^{83}$ The Director of the Islamic Women's Council of Victoria, Joumanah El Matrah, argued against setting up a separate Shari'ah tribunal or court on the ground that it would amount to 'legal ghettoization of Muslims' because 'establishing a parallel system for Muslims does not ensure a culturally appropriate response to justice: it fundamentally locks out Muslims from services they as citizens have a right to access' ${ }^{84}$

Singapore values its dual system just as Australia values its one law for all. Just as it would be difficult for Singapore to repeal AMLA and bring its Muslims under the jurisdiction of the Charter, it is equally difficult to change the Australian formulae. Muslims see difficult possibilities too. A minority advocated that Muslims should be able to have every aspect of life regulated by Shari'ah, ${ }^{85}$ but many more argued that certain aspects of family, inheritance and commerce could be transferred to a Shari'ah entity, ${ }^{86}$ whilst others believe the Australian system already meets the higher objective of the Shari'ah with no change needed (Halim Rane quoted in Merritt 2011c). ${ }^{87}$ Views are diverse and sometimes divisive amongst Muslims, just as they are amongst non-Muslims. However, there is a desire in the wider Australian society to be inclusive and to counter (or at least reduce) disaffection amongst some sectors of the Muslim community. Whether formal accommodation of the Shari'ah would diminish or aggravate alienation continues to be debated.

82 Ibid.

83 Islamic Council of Victoria: Submission 13.

84 Joumanah El Matrah, 'A Sharia Tribunal is a Contradiction of Islam' The Age, 20 October 2009.

85 Sharia4Australia organization.

86 Abdullah Saeed, 'Reflections on the Establishment of Shari'ah Courts in Australia' in Rex Adhar and Nicholas Aroney (eds), Shari'ah in the West (Oxford: Oxford University Press 2010) 231. He also notes at 231 that legal academic Jamila Hussain speculates that most Muslims are happy with Australian law.

87 See Halim Rane quoted in Merritt 2011, also El Matrah 2009, in which a woman's perspective is given on a Sharia tribunal. 


\section{Homogeneity versus Heterogeneity}

One factor contributing to the lack of Muslim consensus on the role for Shari'ah in Australia is that the Muslim population is Australia is not homogeneous, unlike Singapore, where Malay ethnicity, language and culture and Shafi'i school dominate. Australia has Shia Muslims, Ibadis, Sufis, as well as adherents from each of the four Sunni madhabs (schools of law). Australian Muslims comprise 56 different ethnicities and have migrated since the days of first settlement from more than 70 nations. This internal plurality gives a complexity to the Australian situation not replicated in Singapore. This leads to a range of views on the role for Islam in a secular Australia and different ideological commitments to Islam and Shari'ah law. Some Muslims in Australia describe themselves as secular or nominal Muslims. They have an Islamic heritage but have embraced the secular Australian lifestyle - they rarely attend the mosque or observe the five pillars of Islam, they drink alcohol and many have married or are in relationships with non-Muslims. All this is possible and lawful in Australia. Australia also has extremely devout textualist Muslims who desire Shari'ah law to operate in every aspect of their lives and are committed advocates for a Shari'ah Court and laws to be implemented. The plurality that exists across the Muslim world is reflected in Australia where the role for Shari'ah can be informed by models from secular Turkey or theocratic Iran, moderate Indonesia or conservative Saudi Arabia, and viewpoints of new immigrants or fifth-generation Muslim Australians. Such heterogeneity mitigates against dogmatism but also challenges any notion of a Muslim consensus on how Shari'ah should operate in the lives of contemporary Muslims. This stands in contrast to Singapore where the role for the Shari'ah Court and MUIS is not debated, but both are acknowledged as the legitimate custodians and implementers Shari'ah law.

Consensus is also more difficult in a setting where Muslims in Australia are geographically dispersed across a large continent. Singapore has the one Shari' ah Court based at Lengkok Bahru, and kadis in districts easily accessible to all Singaporeans. Australia is vast. Although both countries have roughly the same number of adherents, Muslims in Australia are found in every city from Darwin to Hobart and also in many rural areas. Cairns is almost $3000 \mathrm{~km}$ from Melbourne, and Perth to Sydney is $4000 \mathrm{~km}$, which is essentially the same distance from Perth to Singapore. Establishing a Shari'ah Court or tribunal system would have logistical consequences, thereby raising equity and access issues given the geographic spread of Muslims across Australia. 


\section{Mandatory versus Voluntary Jurisdiction}

The success of the Singaporean approach rests heavily not only on the homogeneity of its Malay Muslim community, who by and large accept the jurisdiction of the Shari'ah Court, the rulings of MUIS and the application of AMLA, but also on the Shari'ah Court's mandatory jurisdiction. Singapore's Muslims have no choice but to submit to the Shari'ah system (unless they leave Islam). It does necessitate the keeping of a reliable record of who is Muslim. In Singapore this can be through self-identification as section 2 of AMLA defines a Muslim as 'a person professing the religion of Islam', but the more important mechanism is through the separate registration system (ROMM) for Muslim births, conversions and marriage. In Australia, because no legal consequences flow from one's religious affiliation, neither religion nor race is put on official marriage, death or birth registers. In Australia, just as religious marriage ceremonies are optional, so too are other personal milestones. Parents can voluntarily choose to have their child undergo a religious ceremony such as a baptism, bar mitzvah, aqiqah (welcoming ceremony for a Muslim baby), christening or other naming service, and similarly choose funeral and burial arrangements in accordance with faith requirements. One's religion is not officially recorded with any government body, which means changing one's religion or becoming atheist remains in the private realm or with the religious bodies' own record-keeping systems.

A Singapore-style system of mandatory jurisdiction for Shari'ah Courts would deny Australian Muslims the same right as other citizens to have cases heard in the common law courts. This would be unlawful discrimination in secular Australia. To deny access to the Federal Circuit Court or the Family Court in Australia based on religious grounds would not be acceptable. Any dual system introduced in Australia would have to be on a voluntary opt-in basis, rather than the mandatory lines of Singapore. Even with an opt-in system, several legal issues would still arise in Australia. The first is that for any government to recognise and cede jurisdiction to a religious court, even on a voluntary basis, constitutional amendments would be needed. Section 116 of the Australian Constitution makes it unconstitutional for any religious test to be required as a qualification for any office or public trust under the Commonwealth. Where a qualification for judicial or arbitral appointment was based on religion, namely Islam, it would be unconstitutional. As already noted, these issues do not arise in Singapore, where Constitution was drafted to entrench legal pluralism not only by creating a 
special legal status for Muslims ${ }^{88}$ but also by specifying that guarantees of 'equality before the law' and 'equal protection' in section 12(3) do not extend to the regulation of personal law. This allows AMLA and the Shari'ah Court to operate in this realm of personal law using personnel appointed and funded by the government. Unlike section 153 of the Singapore Constitution, which provides that the legislature can make laws for 'regulating Muslim religious affairs and for constituting a Council to advise the President in matters relating to the Muslim religion', the Australian government has been given no similar authority. The Australian federal and state governments can (and do) have advisory bodies, such as the Muslim Community Reference Group (MCRG) ${ }^{89}$ and the government-funded National Centre of Excellence in Islamic Studies, ${ }^{90}$ but these are not offices of the government or under a public trust.

Regardless of the constitutional obstacles, there are other concerns with an opt-in system. One is that such a system could intensify Muslim community pressure, even family or spousal coercion, to follow the 'official' Islamic dispute resolution option. In effect, this could undermine their free choice. The second arises from the internal plurality that exists in Australia's Muslim population. This has already been discussed, but were there a government-run Shari'ah Court option, it could in fact impact adversely on plurality of interpretations of Islam that currently flourish. The third is one of public policy. Where there is divergence between religious law and state law, any adverse outcomes for faith adherents become a matter for the religion, in this case Islam, or one for the Australian government or its courts to address. Earlier the issue of limping marriages was mentioned and the predicament for Muslim women that can ensue is frequently cited as a reason for endorsing some form of formal or official Shari'ah Court or Muslim divorce tribunal. ${ }^{91}$ Yet a similar predicament arises in other faith traditions in Australia. Islam is not alone in requiring a religious divorce for its adherents. There are other religions that also do not accept a divorce granted under

88 Constitution section 152.

89 MCRG 'Report Building on Social Cohesion, Harmony and Security' (2006): www.immi.gov.au/living-in-australia/a-multicultural-australia/mcrg_report. pdf.

90 This was an initiative of the Howard government that came into operation in 2007. However, the training of Australian imams proved impractical in the Australian University environment and all funding ended in 2011.

91 Family Law Council of Australia, Report on Cultural Community Divorce and the Family Law Act 1975 (2001) 4 (Executive Summary 17); Essof, n55, $182,186$. 
Australian law dissolves a marriage which took place under their own religious law. Roman Catholics and Jews in Australia ${ }^{92}$ have an ecclesiastical or rabbinical court to make such determinations. These matters remain internal to the religion and do not involve government funding or endorsing of religious courts, nor oversight or the creation of exceptional rules. To do so for one, or for all religions, would seem an unwarranted intrusion into religious freedom generally. Essof, for example, writes that this is needed for limping marriages because Muslim husbands can distort and abuse the Islamic system, and there may be bias and lack of sensitivity from the imams when making decisions that 'could be long, demeaning and emotionally traumatic' 93 for women. Whilst not refuting the legitimate concerns raised, Islamic jurisprudence does favour interpretations that do not create hardship for Muslims through principles of maslaha (public interest). If 'limping marriages' result in hardship for Muslim women because Imams will not grant them an Islamic divorce after they have received a civil one, then ijtihad (independent reasoning) with its many juristic techniques should be utilised to ensure fairer interpretations. Otherwise the problem will remain. As we see from the traditionalist interpretations in divorce cases from Singapore's Shari'ah court (section 47 AMLA) which uphold the classic juristic view that the husband must consent to a khuluk/khula divorce, the outcome for divorcing wives would remain and the problem not rectified. ${ }^{94}$ The presence of a religious court, council or tribunal does not guarantee modernist interpretations, and in practice it could restrict options currently available to Muslim women in Australia's informal system. Currently, if refused a khuluk/khula divorce, the wife is now at least able to seek out another scholar who may apply a different interpretation and grant the divorce. And a wife always has the right to obtain a secular divorce which will provide her with a financial and property settlement

92 In Roman Catholic canon law, there is no such thing as divorce, which means there is nothing for the church to recognise when a secular divorce is granted. Under Catholic Canon law, the exercise is not one of untying people from the marriage bond but of asking whether, according to established criteria, there was ever a marriage in the first place, that is, whether in the circumstances of the case was there ever a marriage, $a b$ initio. Hence it is an annulment that parties must seek from the Church's tribunal, an ecclesiastical court comprised of priests and lay men and women trained in canon law.

93 Essof, n55, 182, 186.

94 In limping marriages, the wife cannot remarry but the husband can, as it is considered lawful for him in Islam to have more than one wife. 
and a determination on parenting arrangements irrespective of the religious process. These are legally enforceable. Arguments put forward that the Family Court should not grant divorces until a Muslim wife can prove she already has a religious divorce ${ }^{95}$ from an Islamic Council would again be discriminatory and would deny her legitimate legal entitlements.

\section{E. Consistency versus Diversity}

In the Australian context, the lack of an official Shari'ah Court or a Majlis Ugama Islam Singapura (MUIS) equivalent has meant there is less certainty and predictability in the application of Islamic law. This arises from the informal unofficial status of Shari'ah law and the heterogeneity of Islam in Australia. In Singapore, there is jurisprudential consistency which gives more certainty and predictability in the law. This comes not only from adhering to predominately to Shafi'i tenets, ${ }^{96}$ as section 33 AMLA requires both the Majlis and the Legal Committee to 'ordinarily follow the tenets of the Shafi'i school of law, unless it is not in the public interest to do so, ${ }^{97}$ but also from the supervisory role of MUIS on the application of Shari'ah law through its Appeal Board and also the MUIS Legal Committee. Section 31 of AMLA sets out the composition of the legal committee, namely '(a) the Mufti; (b) two other fit and proper members of the Majlis; and (c) not more than two other fit and proper Muslims who are not members of the Majlis'. The Mufti of

95 Ibid., n93.

96 Section 33(1) of the Administration of Muslim Law Act specifies that 'the Majlis and the Legal Committee in issuing any ruling shall ordinarily follow the tenets of the Shafi'i school of law' unless that is contrary to public interest. In such situations, section 33(2) states 'the Majlis may follow the tenets of any of the other accepted schools of Muslim law as may be considered appropriate, but in any such ruling the provisions and principles to be followed shall be set out in full detail and with all necessary explanations'.

97 Section 33(1), Administration of Muslim Law Act, Cap 32009 Rev. Ed. Sing with section 33(2) stating that 'the tenets of any of the other accepted schools of Muslim law as may be considered appropriate' can be used in such rulings, but that 'the provisions and principles to be followed shall be set out in full detail and with all necessary explanations'. Rulings can also be made when specifically requested 'in accordance with the tenets of [another] particular school of Muslim law'; see Administration of Muslim Law Act, Cap 3 section 33(3). 
Singapore is the Chairman of the Committee and the Mufti and Committee members are appointed by the President of Singapore, with the advice of the Majlis for the other members. ${ }^{98}$

MUIS also issues fatwas (legal opinions on matters of Islamic law). In keeping with the tradition of ifta (the issuing of fatwas) in Islamic law, a question requiring a fatwa on any point of Islamic law can be asked by 'any person', ${ }^{99}$ by a court of law, including the Shari' ah Court, ${ }^{100}$ and the Committee can 'of its own motion' make and publish any ruling or determination. ${ }^{101}$ The process involves making a draft ruling which if it is unanimously approved by the Legal Committee ${ }^{102}$ will be issued by the Majlis; if it is not unanimously approved, it will be referred to the Majlis who will issue the fatwa in 'accordance with the opinion of the majority of its members'. ${ }^{103}$ This consensual process furthers consistency in the interpretation of Shari'ah law within Singapore. The role given to the Legal Committee provides not only the Shari'ah Court with an authoritative source for interpretations of Sharia law but fulfils that role also for the civil courts. Although the civil courts are not bound by the ruling of the Legal Committee (unlike the Shari'ah Court), the cases show consideration and respect for the Committee's rulings. ${ }^{104}$ That the civil courts have one entity to which they can turn for an Islamic law opinion is a valuable attribute of the Singaporean model. In Australia, who qualifies as an expert in matters of Islamic law can be problematic and has to be established each time to the satisfaction of the court. As with the presentation of other forms of expert evidence, parties can provide their own Shari'ah law expert so the court has to decide between two versions. In the case of Mohammed Salah \& Gastana [2011] FamCA 440 , the parties had contrary expert opinions given by two Muslim scholars. One of the issues in dispute was whether their child's name, given by the mother, was 'blasphemous in the Islamic religion' or not.

\footnotetext{
98 Section 30, Administration of Muslim Law Act, Cap 32009 Rev. Ed.

99 Section 32(1), Administration of Muslim Law Act, Cap 32009 Rev. Ed.

100 Section 32(8), Administration of Muslim Law Act, Cap 32009 Rev. Ed.

101 Section 32(6), Administration of Muslim Law Act, Cap 32009 Rev. Ed.

102 Section 32(4), Administration of Muslim Law Act, Cap 32009 Rev. Ed.

Sing. includes those members present and entitled to vote.

103 Section 32(7), Administration of Muslim Law Act, Cap 32009 Rev. Ed.

104 Saniah Binte Ali \& Anors v Abdullah Bin Ali [1990] 1SLR (R)555.
} Sing.

Sing.

Sing.

Sing.

Sing. 
The component of consistency in the interpretations provided by MUIS can act as a unifying force for Singapore's Muslim community. On the MUIS website some of the more important fatwas are published in Malay or English, or both languages. They include: legal rulings on finance and estate matters; zakat (tithe or charity tax); family matters including family planning; the permissibility of certain medical advances including the stem cell research, organ donation and transplantation, bone marrow transplantation, abortion and advanced medical directives; the permissibility of using ethanol as a food additive; and whether a particular group engaged in deviant teachings (on Islam). These questions would also resonate with many Muslim Australians. The role that fatwas fulfil in the Islamic system is not limited to Muslim countries or to ones like Singapore. Fatwas are equally if not more important in countries like Australia with a preponderance of immigrants rather than a long settled cohesive population. In order to accommodate Islamic religious requirements within a secular framework, it can be argued that fatwas are of even greater significance for Australian Muslims, ${ }^{105}$ as they can ease transition into a secular society and facilitate compliance with Islam in a new social and regulatory context. Research in Australia and also Europe has found the demand for fatwas in the West appears greater than in Islamic countries. ${ }^{106}$

Without an equivalent of Singapore's MUIS Legal Committee or a government-appointed Mufti, there can be confusion and inconsistency in the legal opinions provided, or alternatively, a plethora of views which reflects the voluntary nature of ifta as a tradition and also gives voice to the diversity within the Australian Islamic community. Just as Australian Muslims can select the imam or informal Islamic body of their choice for divorce and other proceedings, Muslims in Australia can turn to a range of sources for fatwas: national organizations such as Australian Federation of Islamic Council (AFIC), the Darulfatwa Islamic High Council, or the National Council of Imams (ANIC); state organizations including

105 Ann Black and Nadirsyah Hosen, 'Fatwas: Their Role in Contemporary Secular Australia' (2009) 18(2) Griffith Law Review: A Journal of Social and Critical Legal Studies 405-27; and Ann Black, 'Fatwas and Surgery: How and Why a Fatwa May Inform a Muslim Patient's Surgical Options' (2009) 79(12) Australian and New Zealand Journal of Surgery 866-71.

106 Alexandre Caeiro, 'Transnational Ulama, European Fatwas, and Islamic Authority: A Case Study of the European Council for Fatwa and Research' in Stefano Allievi and Martin van Bruinessen (eds), Producing Islamic Knowledge: Transmission and Dissemination in Western Europe (Abingdon: Routledge 2010). 
state Islamic Councils and local majlis ulama; local sheikhs or imams at their mosque; or a scholar or organization in an overseas country; and last, but importantly, the Internet's many online fatwa sites. ${ }^{107}$ The process of searching Islamic websites for a religious ruling has been called 'fatwa shopping' or surfing the 'inter-madhab net'. ${ }^{108}$ All sorts of new, alternative and diverse interpretations of Islam can be found online, but traditional or conservative versions appear dominant of some of the most used sites. Some of these overseas Islamic websites ${ }^{109}$ have Muslim scholars who may answer the question without necessarily understanding life in Australia. If the question closely relates to life and social interaction in an Australian context, the answer might not be contextually suitable. ${ }^{110}$ Of course, Singapore's Muslims can also go online to surf the 'inter-madhab' net, but the presence of a national ifta body is a stabilising and unifying force, and fatwas issued by MUIS are cognizant of local conditions.

\section{F. Courts Working Together versus Separately}

The longevity of legal pluralism in Singapore has meant that the Shari'ah and civil courts have had to establish a working relationship. The jurisdiction of each is delineated and there is recurring interaction between the two. For example, the Shari'ah Court lacks powers of enforcement, so its orders for maintenance, mutaah (compensation)

\section{Black and Hosen, n105.}

108 Mohamad Abdalla, 'Do Australian Muslims need a Mufti? Analysing the Institution of Ifta in the Australian Context' in Nadirsyah Hosen and Richard Mohr, Law and Religion in Public Life (Abingdon: Routledge 2010) 214, 221.

109 Islam on-line, based in Doha, Qatar with fatwas issued by a committee of scholars headed by Dr Yusuf Qardawi, www.islamonline.net/livefatwa/english/ select.asp; islamtoday, based in Saudi Arabia with fatwas issued by committee of scholars supervised by Sheikh Salman bin Fahd al-Oadah, www.islamtoday.com/ fatwa_archive_main.cfm; Ask the Imam, South African site with fatwas issued by Mufti Ebrahim Desai, http://islam.tc/ask-imam/index.php; Islam $Q \& A$, based in Saudi Arabia with fatwas issued under supervision of Shaykh Muhammad Saalih al-Munajjid, http://63.175.194.25/index.php?ln=eng; Fatwa on-line, Saudi Arabian site designed to give English speaking Muslims access to translations of officially published Arabic fatwas, www.fatwa-online.com.

110 An example given is the issue of saying 'Merry Christmas'. In Australia this is a cultural practice to mark the season, not a religious observation or one identifying a theological battle between Islam and Christian. Overseas online websites routinely forbid it; for example, the Indonesian website, Shari'ah Online, www.Shari'ahonline.com/new_index.php/id/1/cn/2445 strongly forbids it, as does Islam Q\&A: www.islam-qa.com/en/ref/947/Christmas. 
marriage expenses, custody and property division are enforceable (section 53 AMLA) but not reviewable, by the civil court: the District Court. These orders are enforced as if they were orders of the District Court. There are also cases in which each court will play a distinct role, for example, in distributing a Muslim's estate, the Islamic laws of inheritance are applied by the Shari'ah Court in order to issue an inheritance certificate, ${ }^{111}$ but all grants for probate and letters of administration come from the civil courts. ${ }^{12}$ As noted earlier, the Shari' ah Court has exclusive jurisdiction to make a divorce order but does not have the power to determine matters of spousal maintenance or when a protection order should be issued. These must be remitted to the civil court. In some matters the courts have concurrent jurisdiction. Whilst a Muslim couple must have their divorce heard in the Shari'ah Court, applications for child custody, access and distribution of matrimonial property can be made to 'any court'. This enables a Muslim party during or after divorce proceedings in the Shari'ah Court to make an ancillary application to the civil Family Court where the civil law will be applied. ${ }^{13}$ AMLA requires this to be with the consent of the parties and with the leave of the Shari'ah Court. ${ }^{114}$ Similarly, adoptions fall under the jurisdiction of the civil Family Court, ${ }^{115}$ but the Court takes into account Islamic principles on adoption, to allow the child to keep the name of his or her birth parents, and not that of the adoptive family. ${ }^{116}$ Similarly, the Shari'ah Court can apply legal principles from the civil law system when the issue is one not covered by Islamic law. ${ }^{117}$ Lastly, the criminal offences contained in AMLA Part IX, which include religious offences such as failure to pay zakat, cohabitation outside of marriage, enticing an unmarried woman away from her wali (male guardian, usually her father) and teaching false doctrines about Islam ${ }^{118}$ are heard, determined and sentenced in the civil courts.

111 Section 115, Administration of Muslim Law Act 1966, Act 27 of 1966, 2009 Rev. Ed. Sing.

112 Probate and Administration Act, Cap 215, 2009 Rev. Ed. Sing.

113 Section 17A(2), Supreme Court of Judicature Act, Cap 322, 2009 Rev. Ed. Sing.

114 Section 35A, Administration of Muslim Law Act 1966, Act 27 of 1966, 2009 Rev. Ed. Sing; section 17 Supreme Court of Judicature Act, Cap 322, 2009 Rev. Ed. Sing.

115 Adoption of Children Act, Cap 4, and generally, Abbas, n4, 163, 174.

116 Rahman, n57, 415, 416.

117 Abbas, n115.

118 Sections 134, 135, 137 and 139, Administration of Muslim Law Act 1966, Act 27 of 1966, 2009 Rev. Ed. Sing. 
In Australia, the Family Courts will apply Australian family law to disputes that come before it, regardless of the religion of the parties. When mahr provisions are raised in the context of a post-divorce property settlement, the Family Court will treat mahr either paid or deferred as part of the combined asset pool to be distributed in line with spousal and child maintenance needs and property distribution. Parties will usually try to work out these matters without recourse to litigation, but some do come to the Family Court for resolution. An interesting development in the intersection of Shari'ah law and common law arose recently when the courts in New South Wales had to determine whether a mahr provision should be enforced as a contractual term. The case of Mohamed v Mohamed [2012] NSWSC 852 gives insight into how the 'one law for all' approach plays out in Australian judicial thinking. Faced with paying his wife mahr, the appellant husband argued from an Australian law perspective that the marriage contract was contrary to Australian law on public policy grounds, or alternatively, that the issues involved the applicability of Islamic law which could only be determined by an Islamic law. The court held that mahr agreements could be enforced as long as they complied with the applicable Australian law of contract. The religious component in the contract did not make a case 'non-justiciable',119 and the $\$ 50,000 \mathrm{mahr}$ clause was an enforceable term of a contract in circumstances where the husband had initiated the separation and/or the divorce. If the wife initiated the separation or there was mutual agreement to do so, mahr was not payable. The court found that on the facts, the husband initiated the separation and he was ordered to make the payment. The case is significant because it shows that Australian courts will apply Australian law of contract, not Shari'ah family law, to decide such issues, even where the marital relationship was 'blessed by Islamic Sharia' - the phrase used in the Mohamed's marriage contract. Whether the outcome would be different if determined by a Shari'ah Court applying relevant Islamic principles was irrelevant. It should be noted, however, that the marriage contract in this case had expressly referred to Australian legislation regarding the couple's assets should their marriage end. If the contract had instead specified Islamic law rather than Australian property law, the outcome might have been different. The husband's submission that the Australian court lacked jurisdiction for matters involving Shari'ah law failed, thereby signalling that Australian courts will not cede jurisdiction because a religious

119 Citing Marcovitz v Bruker [2007] 3 SCR 607 at [12-13]. Contra Kaddoura v Hammoud [1988] OJ No.5054 [24]. 
dimension is involved. Harrison AsJ cited Black and Sadiq's view that Shari'ah 'family law cannot be relegated exclusively to a religious tribunal, court or other body to apply and enforce as it is the right of all citizens to bring family matters to the courts of law for determination and have the general law of the land apply'. ${ }^{120}$ That Australia does not deny a Muslim spouse the right to have a case heard in the civil court is an important feature of the Australian 'one law for all' system. When interviewed after the judgment, the wife said it was 'important for Muslim women to fight for their rights'.121 Where a party believes a secular court may provide a better (depending on one's perspective) outcome, then he or she has a right to take that case to the courts for adjudication.

\section{G. Unofficial versus Professional}

In contrast to Australia's ad-hoc system, Singapore's model with a government-funded and government-regulated Shari'ah Court creates a professional and transparent body. Trials and hearings are open, ${ }^{122}$ with the power given in section 46(2) for the court, if it thinks fit, to hold part or all of the proceeding in camera. This power is frequently exercised. Unlike in the common law courts, Shari'ah Court decisions are not formally reported and published, but there is an internal system of records which can be accessed by the legal representatives of the parties. This has allowed a kind of informal system of precedence to develop which facilitates consistency and predictability. Appeals are also possible. Decisions of both the Shari'ah Court and registrars can be taken on appeal to the Shari'ah Appeal Board. ${ }^{123}$ This degree of transparency and appellate review are two important safeguards lacking in Australia's

120 Ann Black and Kerrie Sadiq, 'Good and Bad Sharia: Australia's Mixed Response to Islamic Law' (2011) 17(1) UNSW Law Journal 383, 406 cited at Mohamed v Mohamed [2012] NSWSC 852 [49].

121 N. Berkovic, 'NSW Court Tells Man to Pay Islamic Dowry' The Australian, 1 August 2012.

122 Section 32(1), Administration of Muslim Law Act, Cap 32009 Rev. Ed. Sing. Sections 32 and 46, with the power given in section 46(2) for the court, if it thinks fit, to hold part or all of the proceeding in camera. This power is frequently exercised.

123 Section 55, Administration of Muslim Law Act, Cap 3. The minimum number for the Appeal Board is seven. Currently there are 16 members: seven religious teachers, five district judges and four lawyers. Four of the members are women. Abbas, n115, 163, 185. 
informal system. ${ }^{124}$ In an unofficial system, if an individual or a group of Islamic scholars asserts that they have knowledge and authority to make determination on marriage, inheritance, divorce and financial matters, there are no reliable means to verify this. As hearings take place in private, without lawyers, and without recordings or transcripts, and as there is no formal appeal structure, it is not impossible to know if the reasoning and application of Shari'ah law is fair and accurate. Different outcomes on similar issues can occur. The Singapore model provides a superior system as there is oversight of legal decision making, consistency in application of law, with the added safeguard of an appeal process. Parties are entitled to legal representation 'by advocate or solicitor or by an agent, generally or specially authorized to do so by the Court'. ${ }^{125}$ This does not exclude non-Muslim lawyers. ${ }^{126}$ The Legal Aid Bureau can grant legal aid to litigants in the Shari'ah Court, when the means and merits requirements are met.

\section{CONCLUSION}

The legacies of colonial times still direct the nature and form of the legal systems in Singapore and Australia. The template laid down by the British colonial government has proven resilient for two centuries and seemingly retains the support of each government and its citizens. For Muslims in both countries, it has meant quite different things. Muslims in Australia have choices. Muslims in Singapore have certainty. Choice can be empowering but it can lead to uncertainty, vulnerability and disconnection from mainstream Australia. Certainty on the other hand can mean conformity with singular interpretation of Islam which can enhance a shared religious and ethnic identity. Australian Muslims are afforded the same relationship choices as other Australians: the decisions are theirs to make. Whether they marry or divorce according to Shari'ah law or Australian law, or both; whether they marry a non-Muslim, or marry

124 See Ann Black, 'Accommodating Shariah law in Australia. Can We? Should We?' (2008) 33(4) Alternative Law Journal 214, 217.

125 Sections 32(1) and 39, Administration of Muslim Law Act, Cap 3.

126 AMLA does not specify any qualifications or requirements for Shari'ah legal counsel. Ahmad Nizam Abbas notes that because there are no such mandated requirements or qualifications, legal counsel must find the 'motivation to equip oneself adequately' in Shari'ah law and procedure, and the onus lies with the individual lawyer to engage in self-study, attend courses and seek guidance from experienced practitioners. See Abbas, n115, 163, 181. 
without a wali's consent; whether they simply live together and raise a family outside of marriage, or enter a same-sex union; it is their choice. Singapore's Muslims do not have the same choices, but they have the certainty of knowing that the Shari'ah Court and registry are there to guide and sanction the relationships they enter and exit, in the assurance that as Muslims they are following the path laid down by their faith.

Whereas 'traditionalism' has been the hallmark of Singapore's jurisprudence, ${ }^{127}$ Australia's eclectic Muslim population holds diverse jurisprudential and doctrinal allegiances ranging from 'liberal, progressive, modernist, reformist, secular at one end through to moderate, traditional, orthodox in the mid-range and to conservative, extremist, radical, literalist, neo-revivalist or fundamentalist at the other end'.128 Given this pluralistic context, a formalised and officially recognised Shari'ah Court or Council in Australian would face practical obstacles in terms of the jurisprudence to be applied, the interpretative approach adopted, the persons entrusted with the role of adjudication, and how appointment, oversight and enforcement would occur. In Singapore these obstacles do not arise as it is a streamlined, professional, government-endorsed and legislatively sanctioned system.

The Singapore Constitution facilities the application of Shari'ah law whilst the Australian Constitution creates a significant obstacle to implementing a dual or plural regime based on religious affiliation. Governments in Australia continue to endorse the 'one law for all' approach, rejecting notions of legal pluralism or any formal mechanism to apply Shari'ah law, whilst the government in Singapore is committed to its dual system. Each of these multicultural and multi-religious nations is unwavering in support for the route being taken as the best way to bring about social cohesion and fairness for all.

127 Traditionalism is discussed earlier but can be defined as 'a dogmatic attitude that clings firmly to old ways, resisting innovations or accepting them only unwittingly'. See Rahman, n57, 415, 416.

128 Black and Sadiq, n120, 383, 386. 